\title{
Examining the Teachers, Administrators and Parents' View on Drawbacks of Technology Use in Education
}

\author{
Shqipe Avdiu Kryeziu, Preschool Institution “Ardhmëria I", nn. 60000, Gjilan, Kosova, shqipea.k@hotmail.com \\ *Teuta Agaj Avdiu, Public University "Kadri Zeka ", nn. 60000, Gjilan, Kosova \\ *Arsim Avdiu, Institution: Primary School "Hasan Alia", nn. 61000, Vitia, Republic of Kosova, \\ arsim_avdiu89@hotmail.com
}

\begin{abstract}
As the growth of technology application in the classroom continues to grow, educators and researchers speculate as to how effective the use of technology is. Over time, several researchers have done studies, and conducted observations on technological aids and devices being used in the classroom. Some results were

measurable, and others observable, but mixed results were found. The current research explores the drawbacks of using the technology in education. The purpose of this study is: to show the negative effects of using technology in teaching, to see and understand opinions, experiences, and perceptions of teachers, administrators and parents with educational technologies, and to draw conclusions on the drawbacks of using technology. The research is carried out through mixed methods, respectively quantitative and qualitative methods. Quantitative data collection includes questionnaires prepared for: teachers, administrators and parents. The teacher questionnaire contains 5 questions, the questionnaire for administrators 5 questions and the parent's questionnaire 5 questions as well. The research includes 70 teachers throughout Kosova and 10 administrators of Kosova elementary schools and 60 parents whose children attend the elementary schools where the research was carried out. The results from this research indicate that the use of technology has a positive effect because it encourages students to acquire new knowledge in almost all subjects. However, it is believed that using technology has also its drawbacks. Technology can disconnect students from social interactions, it can distract students from learning, interpersonal interactions are few and far between, it is a resource that not all families can afford, it can create issues of privacy, it can make it easier to cheat etc.
\end{abstract}

Keywords: technology, school, teacher, pupil, teaching.

Received: 16.12.2020 Accepted: 03.01.2021 $\quad$ Published: 03.02.2021

\section{Introduction}

The introduction of information technology systems in schools always tends towards facilitating activities. One of the oldest human activities that was also subject to appropriate changes to the technology evolution was learning. The idea of using computers in order to facilitate the learning process has evolved with the development of the first computers. (Kurti, 2008)

Educational technology in contemporary teaching is an important parameter of pedagogical development which is expressed in several directions:

- Improving the learning environment in the process of theoretical and practical knowledge

- The new mission of teachers and associates in pedagogical action and the educational process

- Implementation of projects in the learning process and evaluation of students' skills in their learning progress. (Murati, 2004)

The major objectives of this research are:

- to gain an insight and understanding of the opinions of teachers, administrators and parents on the use of technology in school;

- to investigate how teachers, administrators and parents perceive the negative effects of technology use;

- to draw conclusions on the drawbacks of using technology in education based on the responses of teachers, administrators and parents of elementary schools in Kosova. 


\section{Use of technology}

Teaching with technology, though considered novel in theory and teaching practice, however, it is old because old pedagogues instead of technology used photographs presented to students and this is considered to be the use of technology. To achieve the highest results in the contemporary teaching process, a lot of technical means, forms and methods of teaching and learning are used, with which you get multiple dimensions. (Zylfiu, 2004)

Schools in Kosovo are creating opportunities for using technology where students and teachers provide massive information on subjects and specific fields. Some students in a school achieve results through the use of technology in the field of language, history, art, etc. (Kraja, 2006)

In contemporary teaching, the use of technology is inevitable in the field of education. In this regard, technology is not only connected to the computer and computer networks but also includes other technology elements such as mobile phones, video projectors, TV, Radio, CD / DVD, camera etc. (Gixhari, 2016)

The process of technology integration in contemporary teaching mainly involves:

- Development of digital teaching materials and multimedia materials;

- Equipping schools with mobile laboratories and applied programs aimed for continuous improvement of teaching quality;

- Integration of ICT in the various subjects of the curriculum;

- Follow up with the improvement of Internet service in all schools and their use during the learning process;

- Creating the necessary capacities through the ongoing training of all teachers for the use of ICT in the teaching process. (Ministry of Education of Albania, 2009)

The technologies we can use in the learning process can be:

- Software presentation

- Visual thinking software

- Web-based diagram and the tools to create charts

- Websites developed by the teacher

- Discussion topics and e-mail

- Links, blogs and wikis

- Interactive software

- WebQuest

- Intelligent teaching systems

- Digital cameras and film-making software

- Auxiliary Technology. (Institute of Education Development, 2015)

The drawbacks of using technology in primary education are understood when using these devices during the learning process. The question arises, how much we use these devices in primary education and does the technology support the learning methods. (Institute of Education Development, 2015)

Technological learning tools should be as successful and compliant with students' requirements as:

- Adapting them to the age of students

- Adapting them to the intelligence level of students

- Punctual operation in technical terms

- Sufficient guidance for their use for the teacher and the student

- Commitment of sufficient time for their use

- Awakening students' curiosity during use

- Meet the requirements of all students

- Drawing conclusions from concrete experiences with students

- Is solely the use of technologies for the implementation of the curriculum sufficient?

- Are all technologies for teaching used, etc. (Zylfiu, 2004)

In the educational system in Kosovo and the development of educational plans are characterized by a low use of contemporary technology which is not integrated into the school curriculum, teaching or education management. The implementation of the strategy for the incorporation of contemporary technology has not progressed as anticipated by the initial plan. The student-computer ratio in Kosovo is 1:46 and is much lower compared to the EU average, where 3-7 students use a computer. ICT Integration in Teaching and Learning remains an important priority to be addressed in the next planning cycle. (MEST, 2016) 


\section{Benefits and drawbacks of using technology in education}

The teaching technology applied to the educational process is a vital aspect because it affects the educational process in a variety of ways: in changing the orientation of the education system, in selecting more valuable and useful information sources from students, distance learning, e-learning, the needs of standardized education quality, the need to understand and implement lifelong learning, etc. (Gixhari, 2016)

Within the applications of technology in education such as video projector, smart board, computers, software, internet, tablet, mobile etc., have been introduced into the education system, resources for contemporary teaching have changed considerably. Different researchers think that there are many advantages to using technology in the classroom, such as: it makes the student more interested in the subject, reduces learning time, and offers opportunities for non-traditional learning, developing contemporary teaching as well as direct use of technology in the classroom. (Situational learning, constructivism and technology, 2015)

The use of audio-visual tools such as tape recordings in contemporary teaching is one of the instruments of great potential as we use sound as evidence that can be repeated several times and is very easy to practice. In particular distinguish four most effective areas of the tape involvement in teaching as: in the foreign language teaching, in sound reproduction during exercise is very effective exercise of individual and collective expression in musical subjects, in registration of students' sentences etc. (Zajazi, 2003)

The use of technology is useful to all students, especially those of elementary education, while writing tasks, thus stimulating writing ability, but this happens when the device being used is constructed from a full keyboard that is appropriate for this age of students. The use of computer equipment supports learning methods for students with different learning abilities, so their use helps students with different conceptual skills as well as special needs students in the quick absorption of new concepts on any topic learning and a genuine development of the lesson with all the students in the classroom. (Situational learning, constructivism and technology, 2015)

Using technology in the teaching process will improve learning outcomes, it is clear that the computer can be used as a tool to facilitate teaching and learning, however, it is equally clear that he cannot replace the pedagogical approach, on what approach should be used during the lesson to achieve the desired learning outcomes, this part of the organization the teacher should plan for himself. (Situational learning, constructivism and technology, 2015)

In the process of using technology, students benefit from:

- Computers improve the student's independent access to education

- Students with special educational needs can perform with the tools that fits them

- Visually impaired learners can access technology through aids

- Students with more serious and multiple problems in learning can easily communicate with the help of technology

- Students who use voice communication tools gain self-confidence

- Using technology impacts students' self-confidence, motivates students to use the internet at home, for school needs as well as for pleasure. (Hapi Dritaret, 2010)

The arguments against online learning are centered largely around the concerns for the loss of traditional classroom face-to-face interaction, and the potential feelings of isolation this can create. The majority of online courses still adopt an Asynchronous approach to learning, and Asynchronous learning limits the amount and depth of interaction amongst both students and instructors. (Wang \& Newlin, 2001) This is supported by a study carried out by (Taylor, 2002), which indicates that online courses often limit interaction activities such as teamwork, which tend to be offered more frequently in the conventional classroom. Moreover, the reduced social and cultural interaction is a major drawback in online education (O'Donoghue, Singh , \& Green , 2004). Similar views are further developed by linking feelings of isolation with a direct impact upon student's motivation levels. When students are sitting alone in front of a computer, they are more prone to distraction. (Schwartzman, 2001). It is also assumed that students who constantly interact via technology can find difficulty in confronting interpersonal interactions. (Schwartzman, 2001)

\section{Research Methodology}

Our research is carried out through mixed methods, respectively quantitative and qualitative methods. Regarding quantitative methods, data will be collected through questionnaires prepared for teachers and administrators of elementary schools of Kosova and parents. The teachers' questionnaire contains 5 questions, the questionnaire for administrators 5 questions and the parents' questionnaire 5 questions as well. With the 
qualitative methods, realistic data is collected from the places where the contemporary teaching is applied. The data obtained are presented through statistical tables processed in computer programs.

\section{Research Questions}

This study will seek to answer the following research questions:

1. Does the use of technology enhance learning?

2. What are the perceptions of teachers regarding the use of technology in classrooms?

3. What are the drawbacks of using technology in education?

\section{Participants}

To provide the most accurate and qualitative data and to make this research more beneficial, our research sample will comprise: 70 teachers throughout Kosova and 10 administrators of Kosova elementary schools and 60 parents. From this selected sample, we will try to include as many elementary schools in Kosova as possible in order to produce more concrete results during the research.

\section{Research progress}

To carry out this research, we have prepared a research plan implemented during the research process in practice. First, we got the permission from the Municipal Departments of Education to conduct the practical research in schools. After we got the permission, the schools administrators were consulted about the research. To carry out this research, the schools' administrators and teachers provided me full support, enabling me to conduct the research with parents as well.

Our research is directed at two dimensions: the research with elementary schools' administrators, as well as with teachers of elementary schools and parents.

The first research plan: in this part of planning, we conducted the research with the teachers and administrators of elementary schools in Kosovo, using a questionnaire prepared for these two research groups. (October, 2019)

The second research plan: after completing the survey for the abovementioned group, in this section we planned and carried out the research with parents, using a questionnaire prepared for parents whose children attend these schools. (October, 2019)

The collected results were analyzed and presented in this study through SPSS software. (January 2020)

\section{Research results and discussion}

To carry out the research, our sample is divided into several groups.

The results obtained through the questionnaire for elementary school administrators are presented below.

Table 1. The gender of the administrators who participated in the survey

\begin{tabular}{|c|c|c|c|c|c|}
\hline \multicolumn{6}{|c|}{ Gender } \\
\hline & & Frequency & Percent & Valid Percent & $\begin{array}{l}\text { Cumulative } \\
\text { Percent }\end{array}$ \\
\hline \multirow[t]{3}{*}{ Valid } & Female & 4 & 40.0 & 40.0 & 40.0 \\
\hline & Male & 6 & 60.0 & 60.0 & 100.0 \\
\hline & Total & 10 & 100.0 & 100.0 & \\
\hline
\end{tabular}

Table 1, shows the gender data for the school administrators; 4 administrators were female, 6 were male.

Table 2. The qualification of the responding administrators

\begin{tabular}{|c|c|c|c|c|c|}
\hline \multicolumn{6}{|c|}{ Education degree } \\
\hline & & Frequency & Percent & Valid Percent & $\begin{array}{l}\text { Cumulative } \\
\text { Percent }\end{array}$ \\
\hline \multirow[t]{3}{*}{ Valid } & Faculty & 7 & 70.0 & 70.0 & 70.0 \\
\hline & Postgraduate studies & 3 & 30.0 & 30.0 & 100.0 \\
\hline & Total & 10 & 100.0 & 100.0 & \\
\hline
\end{tabular}

Table 2 presents data on the education degree of elementary school administrators; 7 administrators have a bachelor degree, 3 have a master degree. 
Table 3. The impact of technology on contemporary teaching - administrators' opinion Do you think technology affects the enhancement of contemporary teaching?

\begin{tabular}{|c|c|c|c|c|c|}
\hline & Frequency & Percent & Valid Percent & Cumulative Percent \\
\hline \multirow[t]{4}{*}{ Valid } & Yes, it does & 8 & 80.0 & 80.0 & 80.0 \\
\hline & No, it doesn't & 1 & 10.0 & 10.0 & 90.0 \\
\hline & $\begin{array}{l}\text { I have no knowledge about } \\
\text { it }\end{array}$ & 1 & 10.0 & 10.0 & 100.0 \\
\hline & Total & 10 & 100.0 & 100.0 & \\
\hline
\end{tabular}

Table 3 contains the data related to the question: Does technology affect the enhancement of contemporary teaching? $80 \%$ of the administrators responded: yes, it does, $10 \%$ no, it doesn't, $10 \%$ I have no knowledge about it.

Table 4. The use of technology in all subjects - administrators' opinion Do you think that technology should be used by the teacher in all subjects?

\begin{tabular}{|l|l|l|l|l|l|}
\hline \multirow{3}{*}{ Valid } & Frequency & Percent & Valid Percent & Cumulative Percent \\
\cline { 2 - 6 } & Yes, I do & 7 & 70.0 & 70.0 & 70.0 \\
\cline { 2 - 6 } & No, it's not necessary & 2 & 20.0 & 20.0 & 90.0 \\
\cline { 2 - 6 } & I don't know & 1 & 10.0 & 10.0 & 100.0 \\
\cline { 2 - 6 } & Total & 10 & 100.0 & 100.0 & \\
\hline
\end{tabular}

Regarding the question: should technology be used in all subjects? we received the following responses from the administrators: $70 \%$ responded: yes, it should be used; $20 \%$ think that it is not necessary and $10 \%$ responded: I do not know. See table 4.

Table 5. The drawbacks of using technology in education- administrators' opinion

Which of the following are the drawbacks of using technology in education?

\begin{tabular}{|c|c|c|c|c|c|}
\hline & \multirow{3}{*}{$\begin{array}{l}\text { Social interaction } \\
\text { Distraction }\end{array}$} & \multirow{2}{*}{$\begin{array}{l}\text { Frequency } \\
1\end{array}$} & \multirow{2}{*}{$\begin{array}{l}\text { Percent } \\
10.0\end{array}$} & \multirow{2}{*}{$\begin{array}{l}\text { Valid Percent } \\
10.0\end{array}$} & \multirow{2}{*}{$\begin{array}{l}\text { Cumulative Percent } \\
10.0\end{array}$} \\
\hline \multirow[t]{6}{*}{ Valid } & & & & & \\
\hline & & 1 & 10.0 & 10.0 & 20.0 \\
\hline & $\begin{array}{l}\text { Loneliness } \\
\text { Cost }\end{array}$ & $\begin{array}{l}\mathbf{1} \\
\mathbf{0}\end{array}$ & $\begin{array}{l}10.0 \\
0\end{array}$ & $\begin{array}{l}10.0 \\
0\end{array}$ & $\begin{array}{l}30.0 \\
0\end{array}$ \\
\hline & $\begin{array}{l}\text { Security } \\
\text { Plagiarism }\end{array}$ & $\begin{array}{l}\mathbf{1} \\
\mathbf{0}\end{array}$ & $\begin{array}{l}10.0 \\
0\end{array}$ & $\begin{array}{l}10.0 \\
0\end{array}$ & $\begin{array}{l}40.0 \\
0\end{array}$ \\
\hline & All of them & 6 & 60.0 & 60.0 & 100.0 \\
\hline & Total & 10 & 100.0 & 100.0 & \\
\hline
\end{tabular}

Regarding the drawbacks of using technology in education, we received different responses from the administrators as it can be seen in figure 5, 10\% responded social interaction; $10 \%$ responded distraction: $10 \%$ responded loneliness; $0 \%$ responded cost; $10 \%$ responded security; $0 \%$ responded plagiarism and $60 \%$ responded all of them (all of the drawbacks listed under the question).

In analyzing the data from our research, the questionnaire with the teachers of elementary schools was also carried out, its results have been analyzed and are presented in more details below.

Table 6. The gender of the responding teachers

\begin{tabular}{|c|c|c|c|c|c|}
\hline \multicolumn{6}{|c|}{ Gender } \\
\hline & & Frequency & Percent & Valid Percent & Cumulative Percent \\
\hline \multirow[t]{3}{*}{ Valid } & Female & 56 & 80.0 & 80.0 & 80.0 \\
\hline & Male & 14 & 20.0 & 20.0 & 100.0 \\
\hline & Total & 70 & 100.0 & 100.0 & \\
\hline
\end{tabular}


Table 6. presents the gender data of the responding teachers, 56 of the respondents were female while 14 were male.

Table 7. Teachers qualifications

\begin{tabular}{|c|c|c|c|c|c|}
\hline \multicolumn{6}{|c|}{ Education degree } \\
\hline & & $\begin{array}{l}\text { Frequenc } \\
\mathrm{y}\end{array}$ & Percent & $\begin{array}{l}\text { Valid } \\
\text { Percent }\end{array}$ & $\begin{array}{l}\text { Cumulative } \\
\text { Percent }\end{array}$ \\
\hline \multirow[t]{4}{*}{ Valid } & Pedagogical & 8 & 11.4 & 11.4 & 11.4 \\
\hline & Faculty & 37 & 52.9 & 52.9 & 64.3 \\
\hline & Postgraduate studies & 25 & 35.7 & 35.7 & 100.0 \\
\hline & Total & 70 & 100.0 & 100.0 & \\
\hline
\end{tabular}

Table 7. presents the data on the education of the responding teachers, 8 finished the Higher Pedagogical School; 37 got the bachelor's degree and 25 got the master's degree.

Table 8. The impact of technology on contemporary teaching - teachers' opinion Do you think technology affects the enhancement of contemporary teaching?

\begin{tabular}{|l|l|l|l|l|l|}
\hline \multicolumn{2}{|l}{} & Frequency & Percent & Valid Percent & $\begin{array}{l}\text { Cumulative } \\
\text { Percent }\end{array}$ \\
\hline \multirow{3}{*}{ Valid } & Yes, it does & 63 & 90.0 & 90.0 & 90.0 \\
\cline { 2 - 6 } & No, it doesn't & 5 & 7.1 & 7.1 & 97.1 \\
\cline { 2 - 6 } & I have no knowledge about it & 2 & 2.9 & 2.9 & 100.0 \\
\cline { 2 - 6 } & Total & 70 & 100.0 & 100.0 & \\
\hline
\end{tabular}

Does the technology affect the enhancement of contemporary teaching? As it can be seen in table 8; $90 \%$ said: yes, it does; $7.1 \%$ said: no, it does not and $2.9 \%$ said: I do not know.

Table 9. The use of technology in all subjects - teachers' opinion Do you think that technology should be used by the teacher in all subjects?

\begin{tabular}{|l|l|l|l|l|l|}
\hline \multicolumn{2}{|l|}{ Valid } & Frequency & Percent & Valid Percent & $\begin{array}{l}\text { Cumulative } \\
\text { Percent }\end{array}$ \\
\cline { 2 - 6 } & Yes, I do & 65 & 92.9 & 92.9 & 92.9 \\
\cline { 2 - 6 } & No, it's not necessary & 4 & 5.7 & 5.7 & 98.6 \\
\cline { 2 - 6 } & I don't know & 1 & 1.4 & 1.4 & 100.0 \\
\hline & Total & 70 & 100.0 & 100.0 & \\
\hline
\end{tabular}

Table 9, reflects the data from teachers' opinions on whether technology should be used in all subjects? $92.9 \%$ think that it should be used; $5.7 \%$ think that it is not necessary, and $1.4 \%$ answered: I do not know.

Table 10. The drawbacks of using technology in education - teachers' opinion

\begin{tabular}{|c|c|c|c|c|c|}
\hline \multicolumn{6}{|c|}{ Which of the following are the drawbacks of using technology in education? } \\
\hline 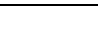 & 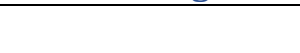 & Frequency & Percent & Valid Percent & Cumulative Percent \\
\hline \multirow[t]{8}{*}{ Valid } & Social interaction & 9 & 12.9 & 12.9 & 12.9 \\
\hline & Distraction & 4 & 5.7 & 5.7 & 18.6 \\
\hline & Loneliness & 4 & 5.7 & 5.7 & 24.3 \\
\hline & Cost & 3 & 4.3 & 4.3 & 28.6 \\
\hline & Security & 4 & 5.7 & 5.7 & 34.3 \\
\hline & Plagiarism & 3 & 4.3 & 4.3 & 38.6 \\
\hline & All of them & 43 & 61.4 & 61.4 & 100.0 \\
\hline & Total & 70 & 100.0 & 100.0 & \\
\hline
\end{tabular}

Regarding the drawbacks of using technology in education, we received different responses from the teachers as it can be seen in figure $10,12.9 \%$ responded social interaction; $5.7 \%$ responded distraction: $5.7 \%$ responded 
loneliness; $4.3 \%$ responded cost; $5.7 \%$ responded security; $4.3 \%$ responded plagiarism and $61.4 \%$ responded all of them (all of the drawbacks listed under the question).

The following results represent the opinions of the elementary schools' parents in Kosova whose children attend the schools where the research was conducted. Their data reflects a reality that is developed daily within these schools.

Table 11. The gender of the responding parents

\begin{tabular}{|l|l|l|l|l|l|}
\hline \multicolumn{5}{|l|}{ Gender } & \multicolumn{4}{l|}{} \\
\hline \multirow{3}{*}{ Valid } & Female & 38 & Percent & Valid Percent & Cumulative Percent \\
\cline { 2 - 6 } & Male & 22 & 63.3 & 63.3 & 63.3 \\
\cline { 2 - 6 } & Total & 60 & 36.7 & 36.7 & 100.0 \\
\hline
\end{tabular}

Table 11, presents the gender data for the responding parents: 38 of the respondents were female while 22 of them were male.

Table 12. The qualification of the responding parents

\begin{tabular}{|c|c|c|c|c|c|}
\hline \multicolumn{6}{|c|}{ Education degree } \\
\hline & & Frequency & Percent & Valid Percent & Cumulative Percent \\
\hline \multirow{4}{*}{ Valid } & High school & 18 & 30.0 & 30.0 & 30.0 \\
\hline & Faculty & 33 & 55.0 & 55.0 & 85.0 \\
\hline & Postgraduate studies & 9 & 15.0 & 15.0 & 100.0 \\
\hline & Total & 60 & 100.0 & 100.0 & \\
\hline
\end{tabular}

In table 12, the education of the responding parents is presented: 18 finished high school, 33 got the bachelor's degree and 9 got the master's degree.

Table 13. The impact of technology on contemporary teaching - parents' opinion Do you think technology affects the enhancement of contemporary teaching?

\begin{tabular}{|c|c|c|c|c|c|}
\hline & & Frequency & Percent & $\begin{array}{l}\text { Valid } \\
\text { Percent }\end{array}$ & $\begin{array}{l}\text { Cumulative } \\
\text { Percent }\end{array}$ \\
\hline \multirow[t]{4}{*}{ Valid } & Yes, it does & 49 & 81.7 & 81.7 & 81.7 \\
\hline & No, it doesn't & 9 & 15.0 & 15.0 & 96.7 \\
\hline & $\begin{array}{l}\text { I have no knowledge about } \\
\text { it }\end{array}$ & 2 & 3.3 & 3.3 & 100.0 \\
\hline & Total & 60 & 100.0 & 100.0 & \\
\hline
\end{tabular}

The data from parents on: Does technology affect the enhancement of contemporary teaching? are presented in table 13; 81.7\% responded: yes, it does; $15 \%$ responded: no, it does not and 3.3\% responded: I do not know.

Table 14. The use of technology in all subjects - parents' opinion Do you think that technology should be used by the teacher in all subjects?

\begin{tabular}{|c|c|c|c|c|c|}
\hline & & Frequency & Percent & Valid Percent & Cumulative Percent \\
\hline \multirow[t]{4}{*}{ Valid } & Yes, I do & 41 & 68.3 & 68.3 & 68.3 \\
\hline & No, it's not necessary & 9 & 15.0 & 15.0 & 83.3 \\
\hline & I don't know & 10 & 16.7 & 16.7 & 100.0 \\
\hline & Total & 60 & 100.0 & 100.0 & \\
\hline
\end{tabular}

Do you think that technology should be used by the teacher in all subjects? As shown in table 14, the parents gave the following answers: $68.3 \%$ think that it should be used, $15 \%$ think that it is not necessary and $16.7 \%$ said: I do not know. 
Table 15. The drawbacks of using technology in education- parents' opinion

\begin{tabular}{|l|l|l|l|l|l|}
\hline \multicolumn{5}{|c|}{ Which of the following are the drawbacks of using technology in education? } \\
\hline \multirow{3}{*}{ Valid } & Frequency & Percent & Valid Percent & Cumulative Percent \\
\cline { 2 - 6 } & Social interaction & 9 & 15.0 & 15.0 & 15.0 \\
\cline { 2 - 6 } & Distraction & 3 & 5.0 & 5.0 & 20.0 \\
\hline Loneliness & 3 & 5.0 & 5.0 & 25.0 \\
\hline Cost & 2 & 3.3 & 3.3 & 28.3 \\
\hline Security & 2 & 3.3 & 3.3 & 31.7 \\
\hline Plagiarism & 2 & 3.3 & 3.3 & 35.0 \\
\hline All of them & 39 & 65.0 & 65.0 & 100.0 \\
\hline Total & 60 & 100.0 & 100.0 & \\
\hline
\end{tabular}

Regarding the drawbacks of using technology in education, we received different responses from the parents as it can be seen in figure 15, 15.0\% responded social interaction; $5.0 \%$ responded distraction: $5.0 \%$ responded loneliness; $3.3 \%$ responded cost; $3.3 \%$ responded security; $3.3 \%$ responded plagiarism and $65.0 \%$ responded all of them (all of the drawbacks listed under the question).

\section{Conclusions}

This study, aiming to determine the attitudes and views of teachers, administrators and parents regarding the technology use in education and its drawbacks was conducted with 70 teachers and 10 administrators of elementary schools in Kosova as well as 60 parents of pupils that attend those elementary schools. Firstly, their attitudes towards technology use were specified and then their views about the drawbacks of using the technology were analyzed. This process was conducted with volunteer teachers, administrators and parents through questionnaires.

The findings indicated that the teachers, administrators and parents had a positive attitude towards the use of technology. The vast majority of teachers, administrators and parents indicated that technology affects the enhancement of contemporary teaching and it should be used by teachers in all subjects. They also added that the integration of technology into learning processes raises students' motivation and interest in the subject. Similarly, many researchers expressed that integrating technology into learning process increased motivation and the length of attention. (Tekbiylk \& Akdeniz, 2010) (Serio, Ibáñez, \& Delga, 2013)

However, as with any other major change, not everyone has received this as a positive message. Another finding pointed to the risk that, although technology can be used in education to attract attention and raise motivation, if being misused, technology can have a number of negative effects. The majority of participants believe that the use of computer technology in the classroom is distracting, reduces social interaction, is responsible for the development of a loneliness, can be addictive, is expensive, bears a risk, is remarkably easy to copy and reproduce and even undermines, the teacher. (Alhumaid, 2019), supports the idea highlighting that the decrease in students' performance, particularly in reading and writing, the dehumanization of the educational environment, the distortion of social relations as well as the isolation that individuals experience when using technology are among the most pervasive and recurrent effects technology has brought to the education.

\section{Recommendations}

Based on the scientific work of this paper and the practical research, the following recommendations are presented below which if taken into account, would help the educational process in the Republic of Kosova and the science of pedagogy in general.

Teachers should be trained on the use and functionalization of technology teaching.

Pupils should be monitored for proper use of technology.

The Ministry of Education, Science and Technology should invest in technological infrastructure (modern technology cabinets).

\section{References}

Alharbi, S. (2016). Benefits and Barriers: Incorporating Assistive Technology in an Inclusive Setting for Primary School Students with Learning Disabilities in Language Arts . American Research Journal of Humanities and Social Sciences, 3. 
Alhumaid, K. (2019). Four Ways Technology Has Negatively Changed Education. Journal of Educational and Social Research, 10-20. doi:10.2478

Aliaj, E., \& Nakaj, ,. E. (2018). Teknologjia në mësimdhënie. Tirana: International Institute for PrivateCommercial- and Competition Law (IIPCCL).

Alkahtani, K. D. (2013). Teachers' Knoëledge and Use of Assistive Technology for Students with Special Educational Needs . Journal of Studies in Education, Vol. 3, No. 2, 68.

Erdem, R. (2017). Students With Special Educational Needs and Assistive Technologies: A Literature Review. The Turkish Online Journal of Educational Technology, 16(1), 137.

Gixhari, A. (2016). Metodat e efektive të komunikimit në mësimdhënie. Tirana: Botimet Streha.

Gjeçi, S. (2018). Kompetencat themelore të të nxënsit. Tirana: International Institute for Private- Commercialand Competition Law (IIPCCL).

Gjino, D. (2018). Qëllimi, risite dhe mangesite e kurrikules se re. Tirana: International Institute for PrivateCommercial- and Competition Law (IIPCCL).

Grillo, K. (2002). Fjalor edukimi. Tirana: Institute of Pedagogical Studies.

Group of author. (2006). Të drejtat e fëmijëve dhe etika e mësimdhënësit. Pristina: KEC.

Hapi Dritaret. (2010). Doracak për arsimtarë përdorimi i teknologjisë qasës në shkolla për fëmijët me nevoja të veçanta. Scopje: Hapi Dritaret.

Havaraj, H. (2018). Teknologjia, ndikuese në dobësimin e aftësive komunikuese te fëmijët. Tirana: International Institute for Private- Commercial- and Competition Law (IIPCCL).

Higgins, S., Xiao, Z., \& Katsipataki, M. (2012). The Impact of Digital Technology on Learning: A Summary for the Education Endoëment Foundation. United Kingdom: Durham University.

Institute of Education Development. (2015). Të nxënit me situata, konstruktivizmi dhe teknologjia. Tirana: Institute of Education Development.

Jaçovska, Z., \& Stojkovska Aleksova, R. (2013). Roli i teknologjisë asistive në procesin e individualizimit të mësimit në shkollat inkluzive. Skopje: USAID.

Kadriu, D. (December, 2011). E-mësimi ngritë rezultatet e të nxënit. Mësuesi i Kosovës(1), 20.

Kraja, M. (2006). Pedagogjia. Tirana: Mileniumi i Ri.

Kurti, E. (2008). Students'experiences on e-learning; an e-learning system in University of Pristina. Kosova: Växjö University.

Manual for ECDL. (2005). Pristina,: Smart bits.

MASHT. (2016). Kurrikula bërthamë për klasën përgatitore dhe arsimin fillor të Kosovës (klasat 0, I, II, III, IV dhe V). Pristina: MEST.

MEST. (2012). Udhëzues për përmirësimin e praktikave në klasë. Pristina: MEST.

MEST. (2016). Kurrikula Bërthamë për Klasën Përgatitore dhe Arsimin Fillor të Kosovës (Grades 0, I, II, III, IV and V). Prishtinë: MEST.

MEST. (2016). Plani Strategjik i Arsimit në Kosovë 2017-2021. Pristina: MEST.

Mexhuni, A. (2014). Integrimi i teknologjisë informative të komunikimit në mësimdhënie dhe nxënie. Pristina: Kosovo Pedagogical Institute.

Ministry of Education of Albania. (2009). Integrimi i teknologjisë së informacionit dhe komunikimit të edukim në Shqipëri. Tirana.

Murati, X. (2004). Pedagogjia e përgjithshme. Shkup: Logos-A.

Musai, B. (2003). Metodologjia e mësimdhënies. Tirana: CDE.

Musai, B. (2003). Metodologjia e mësimdhënies. Tirana: CDE.

Musai, B. (2005). Mësimdhënja dhe të nxënit ndërveprues. Tirana: CDE.

Musai, B., Godole, J., \& Abdurrahmani, T. (2011). Instituti Shqiptar i Medias. Tirana.

Nuredini, V. (2006). Teoria e mësimit. Pristina: University of Pristina.

O’Donoghue, J., Singh , G., \& Green , C. (2004). A comparison of the advantages and disadvantages of IT. Interactive Educational Multimedia, 63-76.

Osmani, S. (1983). Fjalor i pedagogjisë. Tirana: IP.

Schwartzman, R. (2001). Service-learning responds to technological enchantment and intellectual isolation. College Student Journal, 423.

Serio, Á., Ibáñez, M., \& Delga, C. (2013, 03 02). Impact of an augmented reality system on students' motivation for a visual art course. Computers \& Education, 586-596. doi:10.1016

Shimllesha, P. (1988). Pedagogjia. Prizren: Textbook and Learning Tools Institution of SAPK- Prishtina.

Situational learning, constructivism and technology. (2015). Tirana: Institute of Education Development. 
Taylor, R. W. (2002). Pros and cons of online learning - a faculty perspective. Journal of European Industrial Training, 24-37.

Tekbıyık, A., \& Akdeniz, A. (2010). An investigation on the comparison of context based and traditional physics problems. Necatibey Faculty of Education Electronic Journal of Science and Mathematics Education, 4, 123-140.

The manual on using the internet service and e-mail. (2015). Tirana: ADISA.

USAID. (2013). Doracak për arsimtarë për praktika inkluzive kompjuterike me aplikim të teknologjisë ndihmëse. Skopje: USAID.

USAID. (2013). Zhvillimi i shkathtësive të shekullit 21 në klasat me nxënësin në qendër. Pristina: USAID.

USAID. (2015). Pasqyra e praktikave të mira: Shkup, maj 2015 Përdorimi i teknologjisë ndihmëse në arsimin e rregullt në Maqedoni dhe Austri. Skopje: USAID.

Wajszczyk, R. (2014). A study of the impact of technology in early education. Sweden: Uppsala University.

Wang, A. Y., \& Newlin, M. H. (2001). Online Lectures: Benefits for the virtual. TH E Journal (Technological Horizons In Education), 29.

Zajazi, T. (2003). Metodologji të mësimdhënies dhe mësimnxënsies. Skopje: SEE University.

Zylfiu, N. (2004). Didaktika. Pristina: University of Pristina. 